\title{
Thermal properties of cement mortar with different mix proportions
}

\author{
P. Shafigh $^{\mathrm{a}, \mathrm{b}}$, I. Asadi ${ }^{\mathrm{a}, \mathrm{b}} \bowtie$, A.R. Akhiani ${ }^{\mathrm{c}}$, N. B. Mahyuddin ${ }^{\mathrm{a}, \mathrm{b}}$, M. Hashemi ${ }^{\mathrm{d}}$ \\ a. Department of Building Surveying, Faculty of Built Environment, University of Malaya, (Kuala Lumpur, Malaysia) \\ b. Centre for Building, Construction \& Tropical Architecture (BuCTA), Faculty of Built Environment, University of Malaya, \\ (Kuala Lumpur, Malaysia) \\ c. Centre of Advanced Materials, Department of Mechanical Engineering, University of Malaya, (Kuala Lumpur, Malaysia) \\ d. Department of Civil Engineering, Faculty of Engineering, University of Malaya, (Kuala Lumpur, Malaysia) \\ $\triangle$ asadi8564@gmail.com; asadi@siswa.um.edu.my
}

Received 7 July 2019

Accepted 12 March 2020

Available on line 13 July 2020

\begin{abstract}
The energy required for the heating and cooling of buildings is strongly dependant on the thermal properties of the construction material. Cement mortar is a common construction material that is widely used in buildings. The main aim of this study is to assess the thermal properties of cement mortar in terms of its thermal conductivity, heat capacity and thermal diffusivity in a wide range of grades (cement: sand ratio between $1: 2$ and 1:8). As there is insufficient information to predict the thermal conductivity and diffusivity of a cement mortar from its physical and mechanical properties, the relationships between thermal conductivity and diffusivity and density, compressive strength, water absorption and porosity are also discussed. Our results indicate that, for a cement mortar with a 28-day compressive strength in the range of 6-60 MPa, thermal conductivity, specific heat and thermal diffusivity are in the range of $1.5-2.7 \mathrm{~W} /(\mathrm{m} . \mathrm{K}), 0.87-1.04 \mathrm{~kJ} / \mathrm{kg} . \mathrm{K}$ and $0.89-1.26$ $\left(\times 10^{-6} \mathrm{~m}^{2} / \mathrm{s}\right)$, respectively. The scanning electron microscope (SEM) images showed that pore size varied from $18 \mu \mathrm{m}$ to $946 \mu \mathrm{m}$ for samples with different cement-to-sand ratios. The porosity of cement mortar has a significant effect on its thermal and physical properties. For this reason, thermal conductivity and thermal diffusivity was greater in cement mortar samples with a higher density and compressive strength.
\end{abstract}

KEYWORDS: Cement mortar; Thermal conductivity; Heat capacity; Thermal diffusivity.

Citation/Citar como: Shafigh, P.; Asadi, I.; Akhiani, A.R.; Mahyuddin, N.B.; Hashemi, M. (2020) Thermal properties of cement mortar with different mix proportions. Mater. Construcc. 70 [339], e224 https://doi.org/10.3989/mc.2020.09219

RESUMEN: Propiedades térmicas del mortero de cemento con diferentes proporciones de mezcla. La energía requerida para la calefacción y la refrigeración de los edificios depende en gran medida de las propiedades térmicas del material de construcción. El mortero de cemento es un material de construcción común que se usa ampliamente en edificios. El objetivo principal de este estudio es evaluar las propiedades térmicas del mortero de cemento en términos de su conductividad térmica, capacidad térmica y difusividad térmica en una amplia gama de grados (relación cemento: arena entre 1: 2 y 1: 8). Como no hay información suficiente para predecir la conductividad térmica y la difusividad de un mortero de cemento a partir de sus propiedades físicas y mecánicas, también se discuten las relaciones entre la conductividad térmica y la difusividad y la densidad, la resistencia a la compresión, la absorción de agua y la porosidad. Los resultados indican que, para un mortero de cemento con una resistencia a la compresión de 28 días en el rango de 6-60 MPa, la conductividad térmica, el calor específico y la difusividad térmica están en el rango de $1.5-2.7 \mathrm{~W} /(\mathrm{mK}), 0.87-1.04 \mathrm{~kJ} / \mathrm{kg} \cdot \mathrm{K}$ y $0.89-1.26\left(\mathrm{x} 10^{-6} \mathrm{~m}^{2} / \mathrm{s}\right)$, respectivamente. Las imágenes del microscopio electrónico de barrido (SEM) mostraron que el tamaño de poro variaba de $18 \mu \mathrm{m}$ a 946 $\mu \mathrm{m}$ para muestras con diferentes proporciones de cemento:arena. La porosidad del mortero de cemento tiene un efecto significativo en sus propiedades térmicas y físicas. Por esta razón, la conductividad térmica y la difusividad térmica fueron mayores en las muestras de mortero de cemento con mayor densidad y resistencia a la compresión.

PALABRAS CLAVE: Mortero de cemento; Conductividad térmica; Capacidad calorífica; Difusividad térmica.

ORCID ID: P. Shafigh (https://orcid.org/0000-0002-8576-3984); I. Asadi (https://orcid.org/0000-0001-8724-6916); A.R. Akhiani (https://orcid.org/0000-0001-5567-4430); N. B. Mahyuddin (https://orcid.org/0000-0002-0827-0975); M. Hashemi (https://orcid.org/0000-0002-3233-7295)

Copyright: (C) 2020 CSIC. This is an open-access article distributed under the terms of the Creative Commons Attribution 4.0 International (CC BY 4.0) License. 


\section{INTRODUCTION}

The amount of energy required for the heating and cooling of buildings is dependent on the thermal conductivity (k-value), specific heat capacity (C-value) and thermal diffusivity $(\alpha)$ of the building envelope (1). Conduction heat transfer in solids occurs through molecular vibrations and energy transport by free electrons (2). The capacity of a cement-based material to transfer heat through conduction is evaluated based on its k-value $(3,4)$. The $\mathrm{C}$-value of a cement-based material is the amount of energy which is required to raise the temperature of a unit of mass by one degree. Thermal diffusivity indicates the speed of heat transfer through a cement-based material in transient heat-transfer conditions.

Building mortar is prepared by mixing cementitious material, fine aggregate and water in appropriate proportions. Depending on its various applications, it can be categorised as either masonry or plastering mortar. Masonry mortar is used to bind bricks, stones and blocks in the construction process. Plaster mortar is applied to the walls of the building to create a smooth, durable surface.

Cement mortar contains cement as a binder, sand as a fine aggregate, water and also admixture in some cases. Changing the type and amount of each component causes variations in the mortar's thermal and mechanical properties, affecting its suitability for different applications. Kim et al. (5) evaluated the effect of variations in type of mixture, age, fine aggregate fraction, total aggregate volume fraction, water-to-cement (W/C) ratio, temperature and humidity conditions on the thermal conductivity of mortar. They reported that the factor with the greatest influence on the k-value of mortar is the type of mixture. Most studies only consider thermal conductivity when evaluating a mortar's thermal behaviour, regardless of its heat capacity and thermal diffusivity. However, several researchers have evaluated the effect of different cementitious materials and different types of aggregate on the k-value of mortar. Demirbo®a (6) evaluated the $\mathrm{k}$-value of a mortar in which cement was replaced with silica fume (SF), fly ash (FA) or blast furnace slag (BFS). The test results showed that using these cementitious materials reduces the thermal conductivity of mortar by $17 \%, 31 \%$ and $40 \%$ for SF, $14 \%$, $26 \%$ and $33 \%$ for FA and between $12 \%$ and $14 \%$ for BFS. Lertwattanaruk et al. (7) measured the k-value of different mortars for masonry and plastering in which cement was replaced by ground seashells, like short-necked clam, green mussel, oyster and cockle shells. They reported that the incorporation of ground seashells can reduce the $\mathrm{k}$-value compared to conventional mortar. Mo et al. (8) measured the k-value of a mortar in which the cement was replaced by palm oil fuel ash (POFA). Two types of fibre (polypropylene and acrylic fibres) were also added to the mixture. They reported that the $\mathrm{k}$-value of POFA mortar was lower than that of the mortar without POFA. The k-values of the mortars without POFA were between 1.44 and $2.25 \mathrm{~W} /$ $(\mathrm{m} \cdot \mathrm{K})$, whereas for the mortars with 50\% POFA the $\mathrm{k}$-values were in the range of 0.77 to $1.4 \mathrm{~W} /(\mathrm{m} \cdot \mathrm{K})$.

Olmeda et al. (9) evaluated the effect of high-sulphur-content petroleum coke on the k-value of mortar as a fine aggregate replacement. They reported that the k-value of mortar decreases by up to $80 \%$ when sand is partially replaced with petroleum coke. Baite et al. (10) considered the k-value of a mortar in which the fine aggregate is replaced by coal bottom ash. They reported that utilising coal bottom ash as the fine aggregate reduces the $\mathrm{k}$-value of cementitious materials. Herrero et al. (11) evaluated the thermal performance and mechanical properties of a mortar containing plastic waste. They found that the higher the plastic content in the compound, the lower the thermal conductivity. A plastic waste (PE) component of $20 \%$ causes thermal conductivity to drop by more than $50 \%$ of its original value.

Widodo et al. (12) evaluated the k-value of a mortar in which the fine aggregate was replaced with pumice breccia, discovering that the k-value decreased by up to $40 \%$. Kockal (13) evaluated the $\mathrm{k}$-value of a mortar in which the normal fine aggregates were replaced by porous slag (SS), acidic pumice (AS) and basic pumice (BS). They found that the $\mathrm{k}$-values of SS, AS and BS were about 0.6, 0.9 and $1.0 \mathrm{~W} /(\mathrm{m} \cdot \mathrm{K})$, respectively. Generally, a review of the available literature reveals that replacing cement and normal fine aggregate with (eco-friendly) waste materials can reduce the k-value of mortar, with the result depending on the type of waste material used.

Different researchers have selected various cement-to-sand ratios $(\mathrm{C} / \mathrm{S})$ for different applications. Based on the available literature, most researchers selected a cement-to-sand ratio of between 1:0.5 and 1:8 $(6,7,9-12,14,15)$. This work indicates that a conventional cement mortar with a compressive strength in the range of 1.7 to $55.0 \mathrm{MPa}$ may have a thermal conductivity of between 0.53 and $2.50 \mathrm{~W} /$ $(\mathrm{m} \cdot \mathrm{K})$. This is a very wide range of $\mathrm{k}$-values for mortar. In different simulation studies, different $\mathrm{k}$-values were assumed; there are no guidelines or specifications for selecting an accurate value for thermal conductivity based on strength grade. In addition, there is little information about the other thermal properties, such as specific heat capacity and thermal diffusivity, of different grades of conventional cement mortar. Furthermore, considering that measuring the thermal properties of mortar requires specialist equipment and a specific set of testing conditions, developing prediction models that allow thermal properties to be estimated based on other physical and mechanical properties will result in time and cost savings. Therefore, the aim of this study is to 
investigate the thermal properties, such as thermal conductivity, heat capacity and thermal diffusivity, of different grades of conventional cement mortar with different mix proportions while keeping the type of cement, sand, curing conditions and testing methods constant. In addition, it aims to develop predictive models for estimating the thermal properties of cement mortar. The relationship between thermal conductivity and diffusivity and certain physical and mechanical properties is also discussed.

\section{MATERIALS AND METHODS}

\subsection{Materials}

In this study, we used ordinary Portland cement (OPC) meeting the specifications of MS522 part 1:2003 (16), with compressive strengths of $36 \mathrm{MPa}$ at 7 days and $48 \mathrm{MPa}$ at 28 days. The specific gravity and specific surface area of the OPC used were 3.14 and $3510 \mathrm{~cm}^{2} / \mathrm{g}$, respectively. The chemical properties of the OPC are shown in Table 1. For all mixtures, we used local mining sand with a fineness modulus of 2.6, saturated-surface-dry (SSD) specific gravity of 2.55 , water absorption of $1.5 \%$ and maximum particle size of $4.75 \mathrm{~mm}$. The grading of the sand used is shown in Figure 1.

\subsection{Sample preparation}

Seven different mixes were prepared, each with a different cement-to-sand $(\mathrm{C} / \mathrm{S})$ ratio $(1: 2,1: 3,1: 4$, 1:5, 1:6, 1:7 and 1:8) and good workability (flow of
$190 \pm 5 \mathrm{~mm}$ ). This range of $\mathrm{C} / \mathrm{S}$ ratios was selected as these are the most commonly found in mortars used in practice and other research. The proportions for all mixes are shown in Table 2. As can be seen from the table, the W/C ratio of mortars with a lower cement content was higher. This is due to the need to ensure equivalent workability for all mixes.

A cylinder with a diameter of $100 \mathrm{~mm}$ and a height of $200 \mathrm{~mm}$ was cast for the thermal conductivity, specific heat capacity and porosity tests. A cube with dimensions $100 \mathrm{~mm} \times 100 \mathrm{~mm} \times 100$ $\mathrm{mm}$ was prepared for use in the density, compressive strength and water absorption tests. The samples were removed from the moulds after $24 \mathrm{~h}$. The specimens were cured in normal water with a temperature of $23 \pm 3{ }^{\circ} \mathrm{C}$ until reaching testing age. All properties were evaluated at 28 days of curing, except compressive strength which was measured at both 7 and 28 days.

\subsection{Testing methods}

In this study, we tried to prepare the mixtures with an approximate fixed workability. For this reason, the W/C ratio varied depending on the cementto-sand ratio (from 1:2 to 1:8). The workability of fresh mortar was evaluated using the flow table test according to ASTM C 1437-1 (17). The truncated cone was filled with fresh mortar in three layers, each tamped 20 times with a tamping rod. Next, the mould was lifted away and 25 strokes were applied to the table over 15 seconds (Figure 2). Finally, the change in mortar diameter was measured in three

TABLE 1. The chemical compositions and LOI of OPC ( $\%$ by mass).

\begin{tabular}{|c|c|c|c|c|c|c|c|c|c|c|c|c|}
\hline $\begin{array}{l}\text { Chemical } \\
\text { Composition }\end{array}$ & $\mathrm{SiO}_{2}$ & $\mathrm{CaO}$ & $\mathrm{Al}_{2} \mathrm{O}_{3}$ & MgO & $\mathrm{Fe}_{2} \mathrm{O}_{3}$ & $\mathbf{P}_{2} \mathbf{O}_{5}$ & $\mathrm{MnO}$ & $\mathrm{K}_{2} \mathrm{O}$ & $\mathrm{TiO}_{2}$ & $\mathrm{SO}_{3}$ & SrO & LOI \\
\hline OPC & 20.14 & 60.82 & 3.89 & 3.10 & 3.35 & 0.064 & 0.14 & 0.24 & 0.16 & 2.25 & 0.02 & 2.23 \\
\hline
\end{tabular}

LOI: Loss on ignition

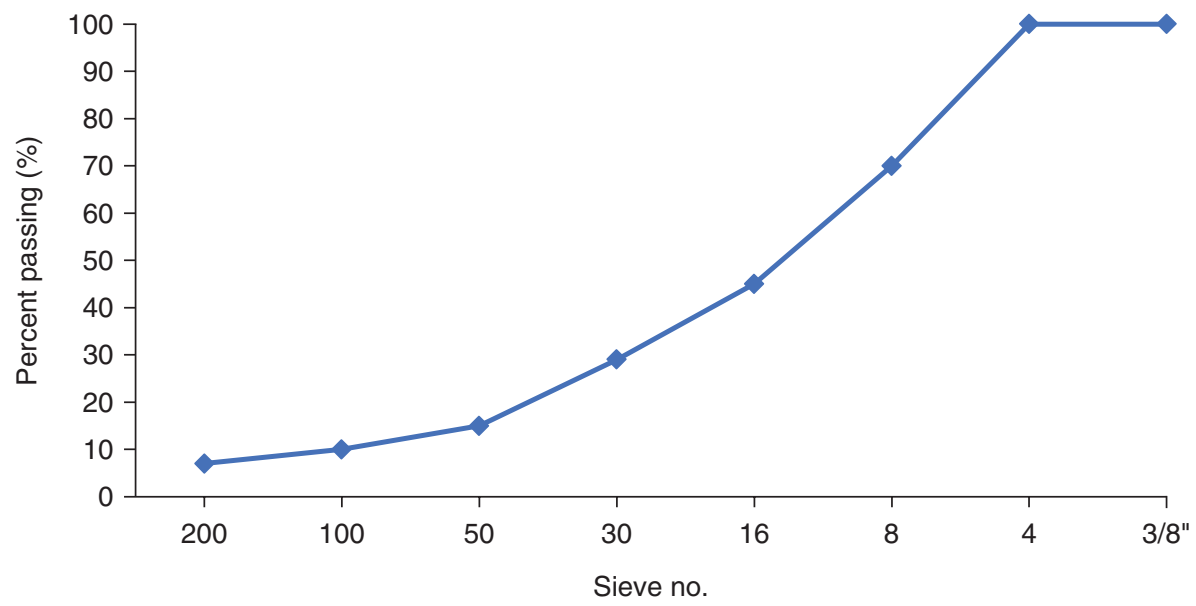

FIGURE 1. Sieve analysis for sand. 
TABLE 2. Mixture composition.

\begin{tabular}{lcccccc}
\hline Mix No & $\begin{array}{c}\text { Cement } \\
\left(\mathbf{k g} / \mathbf{m}^{3}\right)\end{array}$ & $\begin{array}{c}\text { Sand } \\
\left(\mathbf{k g} / \mathbf{m}^{3}\right)\end{array}$ & $\begin{array}{c}\text { Water } \\
\left(\mathbf{k g} / \mathbf{m}^{3}\right)\end{array}$ & $\mathbf{C : S}$ & $\mathbf{W} / \mathbf{C}$ & $\begin{array}{c}\text { Flow } \\
(\mathbf{m m})\end{array}$ \\
\hline M1:2 & 639.5 & 1290.0 & 270.3 & $1: 2$ & 0.42 & $190 \pm 5$ \\
M1:3 & 488.8 & 1466.6 & 244.4 & $1: 3$ & 0.50 & \\
M1:4 & 389.8 & 1559.4 & 250.6 & $1: 4$ & 0.64 & \\
M1:5 & 326.4 & 1626.6 & 246.9 & $1: 5$ & 0.75 & \\
M1:6 & 273.2 & 1639.7 & 286.9 & $1: 6$ & 1.05 & \\
M1:7 & 239.5 & 1676.6 & 283.8 & $1: 7$ & 1.18 & \\
M1:8 & 212.4 & 1715.8 & 271.7 & $1: 8$ & 1.27 & \\
\hline
\end{tabular}

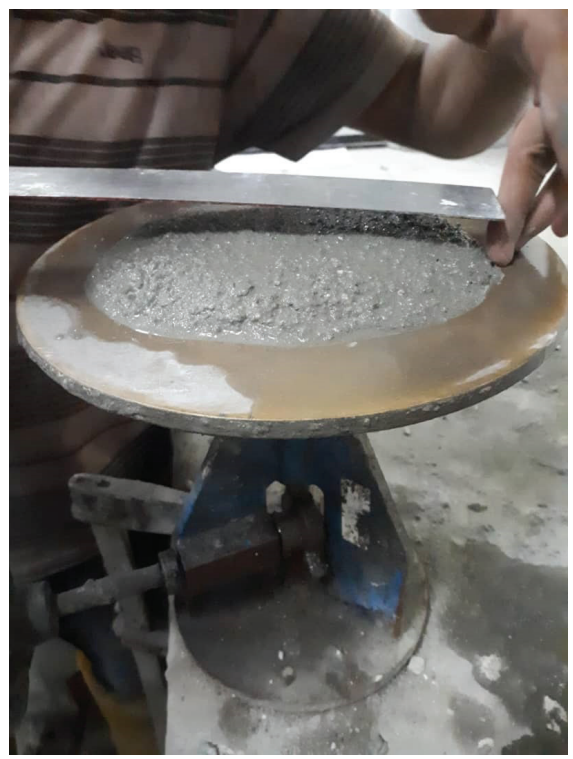

Figure 2. The flow table test.

directions. The average diameter was reported as mortar flow in Table 2.

At 28 days, three cylindrical specimens $(100 \mathrm{~mm} x$ $200 \mathrm{~mm}$ ) were selected to measure thermal conductivity. The samples were dried in an oven at $105^{\circ} \mathrm{C}$ for $24 \mathrm{~h}$ to remove all moisture. The $\mathrm{k}$-value of the specimens was determined with a KD2-PRO analyser using a TR1 needle. A TR1 sensor $(2.4 \mathrm{~mm}$ in diameter and $100 \mathrm{~mm}$ in length) is capable of measuring thermal conductivity in the range of $0.1 \mathrm{~W} /$ $(\mathrm{m} \cdot \mathrm{K})$ to $4 \mathrm{~W} /(\mathrm{m} \cdot \mathrm{K})(18)$. A pilot pin was inserted to the uncured specimens to produce a hole matching the size of the TR 1 sensor. The sensor's relatively long read times (10 minutes for each reading at 15-minute intervals) help minimise errors associated with the large-diameter needle. The contact between needle and specimen was guaranteed by applying thermal grease to the hole (Figure 3).

The KD2-PRO analyser works by heating the needle for a certain period of time $\left(\mathrm{t}_{\mathrm{h}}\right)$ and monitoring the temperature during heating and cooling. The temperature during heating and cooling
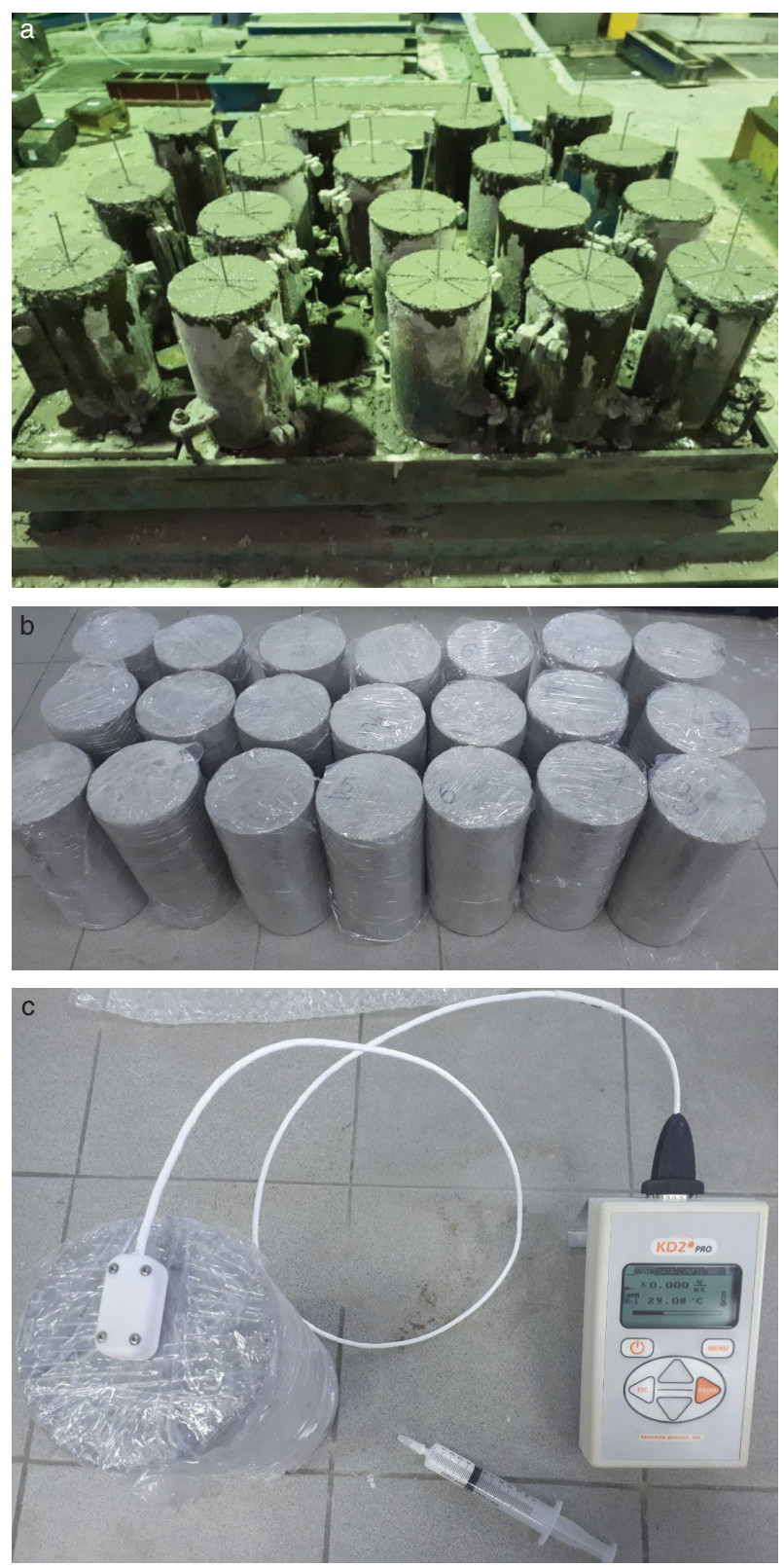

FIGURE 3. The thermal conductivity measurement process: (a): prepared sample in fresh state, (b): wrapping the dried samples with plastic and (c): the k-value measurement.

is calculated using Equation [1] and Equation [2], respectively (18):

$$
\begin{gathered}
T=m_{0}+m_{2} t+m_{3} \ln t \\
T=m_{1}+m_{2} t+m_{3} \ln \frac{t}{t-t_{h}}
\end{gathered}
$$

Where $m_{0}$ and $m_{1}$ are the initial temperature, $m_{2}$ is the rate of background temperature drift and $m_{3}$ 
is the gradient of a line relating temperature rise to logarithm of temperature.

Consequently, thermal conductivity can be calculated using the following Equation [3] based on heat flux (q):

$$
k=\frac{q}{4 \pi m_{3}}
$$

The influence of ambient temperature and humidity on the samples should be kept to a minimum, in order to achieve a more accurate value while using the KD2-PRO. Therefore, the specimens were wrapped in a plastic sheet to minimise the effect of ambient moisture and keep the sample in a dry condition.

The specific heat capacity of cement mortar in dry conditions can be calculated using the law of mixtures. Given a well-hydrated sample, the law of mixtures is a reasonable predictor for the heat capacity of mortar, and accounts for both the 'bound water' and 'physical water' heat capacity (19). This Equation [4] is based on the specific heat capacity of a mixture as a function of its composition (20):

$$
\mathrm{C}_{p}=\sum \boldsymbol{F}_{i} C_{p i}
$$

Where $C_{p}$ is the specific heat of mixture $(\mathrm{kJ} /$ $\mathrm{kg} . \mathrm{K}), \mathrm{C}_{\mathrm{pi}}$ is the specific heat of each component and $F_{i}$ is the weight fraction of each component.

Differential scanning calorimetry (DSC) at a heating rate of $10{ }^{\circ} \mathrm{C} / \mathrm{min}$ was used to measure the specific heat of cement and sand. The specific heat capacity of water is $4.18(\mathrm{~kJ} / \mathrm{kg} \cdot \mathrm{K})$ in $23{ }^{\circ} \mathrm{C}$. The measured specific heat capacity of cement and sand in the range of $20^{\circ} \mathrm{C}$ to $50{ }^{\circ} \mathrm{C}$ is shown in Figure 4. However, the specific heat capacity of bounded water for hydration as a gel product is 2.2 $(\mathrm{kJ} / \mathrm{kg} \cdot \mathrm{K})(21)$. The total amount of chemical and physical bound water for the hydration of cement is 0.42 grams per gram of cement. The remainder is solely to improve the workability of the mortar and is vaporised when the mortar is dried (22).

The following Equation [5] was used to calculate thermal diffusivity:

$$
\alpha=\frac{K}{\rho C}
$$

Where $\alpha$ is thermal diffusivity $\left(\mathrm{m}^{2} / \mathrm{s}\right), k$ is the thermal conductivity of a material $(\mathrm{W} / \mathrm{m} \cdot \mathrm{K}), \rho$ is density $\left(\mathrm{kg} / \mathrm{m}^{3}\right)$ and $\mathrm{C}$ is specific heat $(\mathrm{J} / \mathrm{kg} \cdot \mathrm{K})$.

A compressive strength test was carried out on $100-\mathrm{mm}^{3}$ cubic specimens. Like the cylindrical specimens, the cubic specimens were cured in water and tested at the ages of 7 and 28 days. A water-absorption test was also carried out on the $100-\mathrm{mm}^{3}$ cubic samples at the age of 28 days. The specimens were dried in an oven for $24 \mathrm{~h}$ prior to the test. The initial and final water absorption of the specimen were determined after full immersion in water for $30 \mathrm{~min}$ and $72 \mathrm{~h}$, respectively.

The porosity test was carried out on three cylindrical specimens, each with a diameter of $100 \mathrm{~mm}$ and a height of $200 \mathrm{~mm}$, after 28 days of curing. One piece $5 \mathrm{~cm}$ thick was cut from each sample. Next, the samples were dried in an oven at $105^{\circ} \mathrm{C}$ for $24 \mathrm{~h}$ to remove moisture. The vacuumed samples were then filled with water. The amount of water held by the sample is a measure of its porosity, as follows (23):

$$
\mathrm{P}=\frac{m_{b}-m_{a}}{m_{a}} \times 100
$$

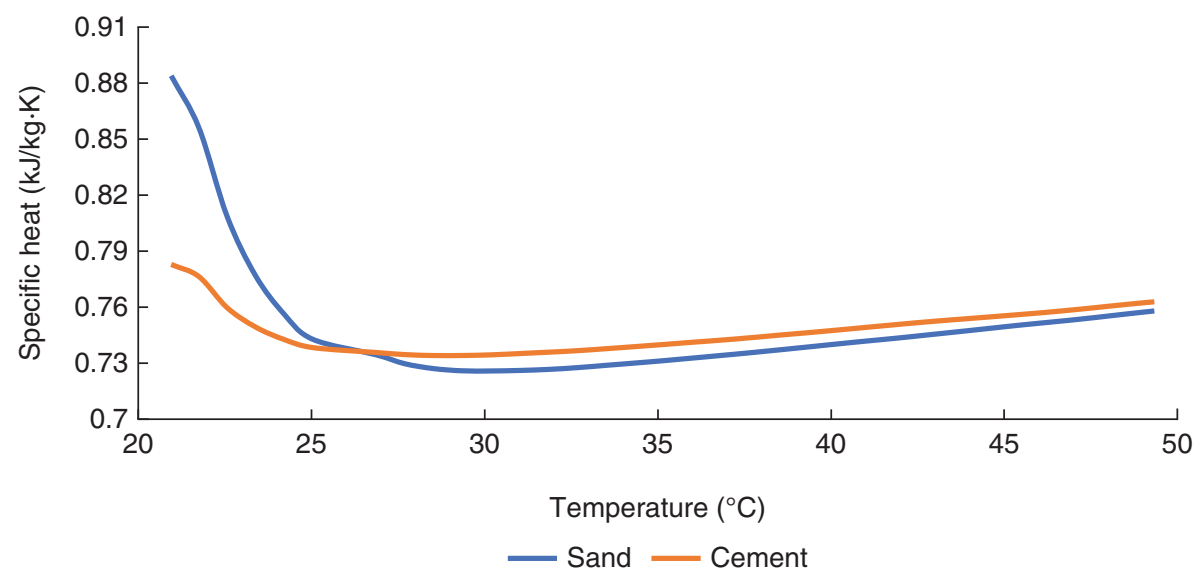

FIGURE 4. Specific heat capacity of cement and sand. 
Where $\mathrm{P}$ is porosity $(\%), m_{\mathrm{a}}$ is oven-dry weight $(\mathrm{kg})$ and $m_{\mathrm{b}}$ is saturated surface dry weight $(\mathrm{kg})$.

\subsection{Compressive strength test results}

Figure 5 shows the compressive strength of cement mortars containing different $\mathrm{C} / \mathrm{S}$ ratios at the ages of 7 and 28 days. As expected, sample M1:2 had the highest strength with values of $47.7 \mathrm{MPa}$ and $60.2 \mathrm{MPa}$, and sample M1:8 had the lowest compressive strength at $4.4 \mathrm{MPa}$ and $6.4 \mathrm{MPa}$. The compressive strength of the mortars was reduced by decreasing the C/S ratio in mixtures with the same workability. The 28-day compressive strength of mix M1:8 is about $89 \%$ lower than M1:2. This mix is classified as type $\mathrm{N}$ as per ASTM C270 (24), which shows that it can be used in external and internal load-bearing walls.

\section{RESULTS AND DISCUSSION}

\subsection{Thermal properties}

Table 3 shows the measured thermal conductivity, specific heat capacity and calculated thermal diffusivity of each cement mortar.
The k-value indicates the cement mortar's capacity for steady-state conduction heat transfer. Low thermal conductivity results in good thermal performance, indicating that the mortar is suitable for use as a heat-resistant material. As can be seen from Table 3, with the exception of the mortar with a cement-to-sand ratio of 1:3, the $\mathrm{k}$-value declines as the cement-to-sand ratio $(\mathrm{C} / \mathrm{S})$ is decreased. Moreover, M1:8 has the lowest k-value, about 45\% lower than mix M1:2. However, M1:3 shows the highest $\mathrm{k}$-value of all the mortars.

The k-value for M1:3 is greater than for M1:2 despite its higher water-to-cement ratio (W/C) and its lower cement-to-sand ratio $(\mathrm{C} / \mathrm{S})$. This may be related to the different proportions of cement and sand in each mix. The larger amount of sand in M1:3 in comparison with M1:2 reduces the potential porosity between cement and sand and results in homogenous slurry. In addition, Mix M1:2, with a higher cement content (about 31\%) and lower W/C ratio $(16 \%)$, is a stickier mixture in its fresh state compared to mix M1:3. This means that given the same vibration method and time, more trapped air will remain inside the mixture, which can be seen in the porosity test results of the hardened mortars (Table 3).

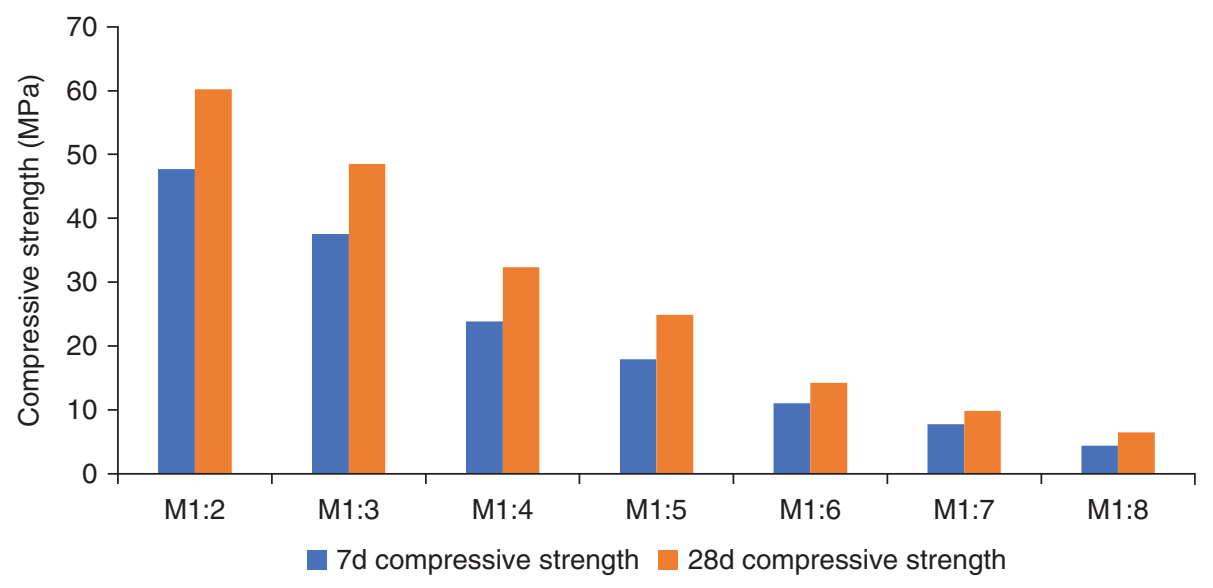

Figure 5. Compressive strength value.

TABLE 3. Thermal properties of cement mortars.

\begin{tabular}{lccccc}
\hline Sample ID & $\begin{array}{c}\text { Thermal conductivity } \\
(\mathbf{k}-\mathbf{v a l u e})(\mathbf{W} / \mathbf{( m} \cdot \mathbf{K}))\end{array}$ & $\begin{array}{c}\text { Specific heat capacity } \\
(\mathbf{C}-\mathbf{v a l u e})(\mathbf{k J} / \mathbf{k g} \cdot \mathbf{K})\end{array}$ & $\begin{array}{c}\text { Thermal diffusivity } \\
\left(* \mathbf{1 0}^{-6} \mathbf{~ m}^{\mathbf{2}} / \mathbf{s}\right)\end{array}$ & $\begin{array}{c}\text { Oven-dry density } \\
\left(\mathbf{k g} / \mathbf{m}^{\mathbf{3}}\right)\end{array}$ & $\begin{array}{c}\text { Porosity } \\
(\mathbf{\%})\end{array}$ \\
\hline M1:2 & 2.43 & 1.04 & 1.03 & 2233.2 & 7.1 \\
M1:3 & 2.79 & 0.98 & 1.26 & 2247.4 & 6.3 \\
M1:4 & 2.40 & 0.94 & 1.18 & 2138.4 & 8.4 \\
M1:5 & 2.23 & 0.91 & 1.18 & 2053.1 & 8.9 \\
M1:6 & 1.99 & 0.89 & 1.09 & 2023.5 & 10.7 \\
M1:7 & 1.67 & 0.88 & 0.95 & 1984.7 & 11.3 \\
M1:8 & 1.54 & 0.87 & 0.89 & 1973.4 & 11.7 \\
\hline
\end{tabular}


As can be seen from Table 2, mixes with a W/C ratio of M1:4 to M1:8 score significantly higher than mix M1:2. As mentioned in the research methodology section, extra water is required to maintain a high workability similar to mix M1:2. Consequently, this extra water creates more porosities inside the mixture, and higher porosity results in a lower k-value.

The heat capacity (C-value) of cement mortar indicates its capacity to store heat. Mortar with a high $\mathrm{C}$-value is not affected by sudden changes in temperature. M1:8, with a C-value of around $0.87 \mathrm{~kJ} / \mathrm{kg} \cdot \mathrm{K}$, has the lowest specific heat capacity of all mortar types tested. The highest $\mathrm{C}$-value was for mix M1:2, at around $20 \%$ greater than that of mix M1:8

The thermal diffusivity of a cement mortar indicates its transient heat conductivity. Cement mortars with low thermal diffusivity are considered heat insulators in transient heat transfer conditions. The thermal diffusivity of M1:3 is greater than those of the other mortars due to its higher k-value. M1:8 has the lowest thermal diffusivity, at around 30\% lower than $\mathrm{M} 1: 3$.

\subsection{Relationship between thermal and physical/ mechanical properties of cement mortar}

Knowing the thermal properties of cement mortar is essential for analysing energy consumption in buildings. To measure thermal properties, special tools are required. Preparing the samples correctly, setting up the test and the testing procedure itself take time. Therefore, using equations to predict the thermal properties of cement mortar is essential to save time and costs. The high coefficient of determination $\left(\mathrm{R}^{2}\right)$ shows the strength of the correlation (25). Most relationships reported in the literature are between the thermal conductivity and density of cement-based materials, and there are very few existing equations to predict thermal conductivity based on the other physical and mechanical properties of the material. In addition, there is little information about the thermal diffusivity of cement-based materials, and very few predictive models. The following sections present the relationship between thermal conductivity and thermal diffusivity and certain physical/mechanical properties of cement mortar,
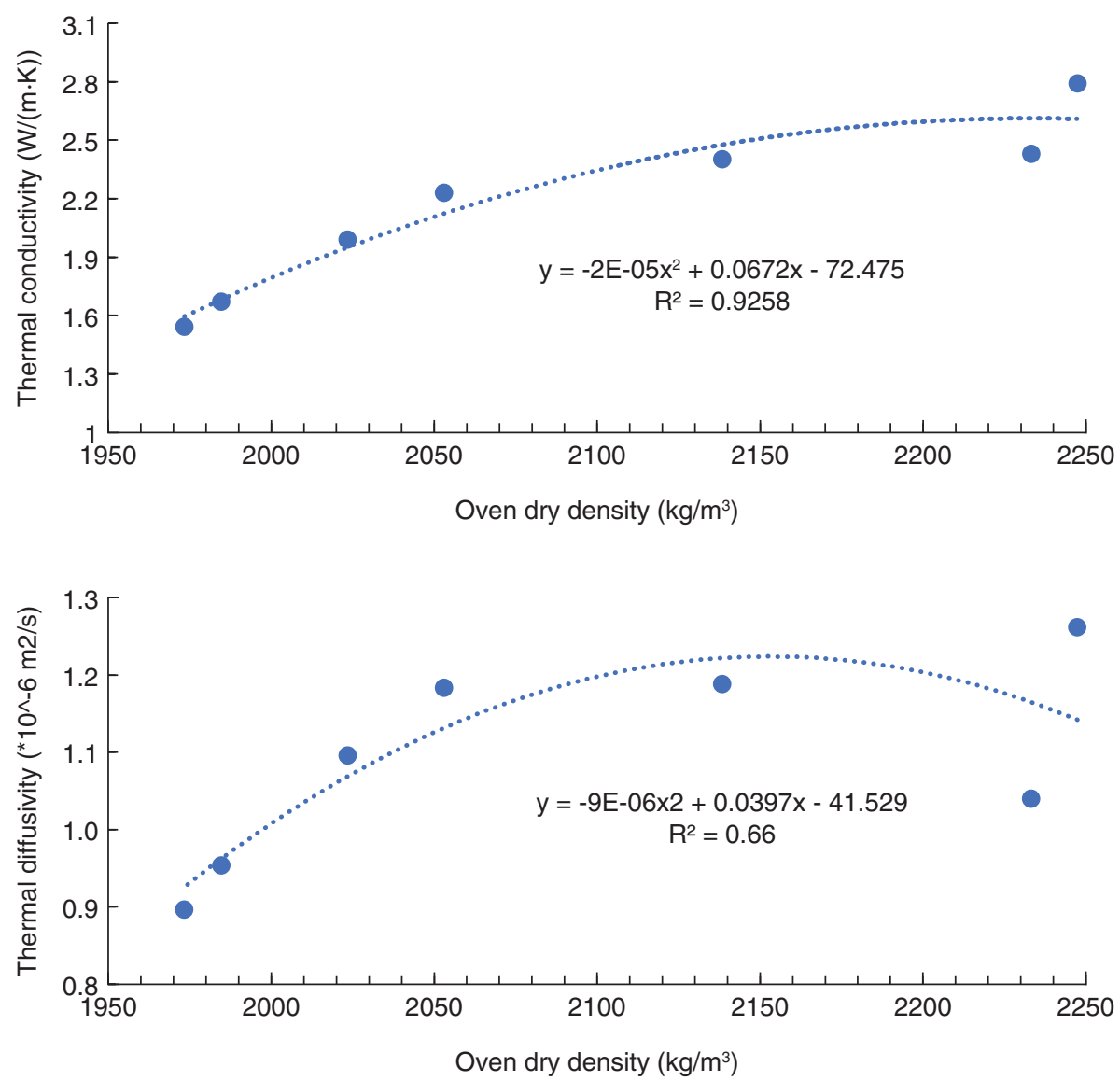

FIGURE 6. The relationship between oven-dry density and the thermal properties of cement mortar. 
such as oven-dry density, compressive strength, water absorption and porosity.

\subsubsection{Oven-dry density}

Figure 6 shows the thermal properties of cement mortar as a function of oven-dry density. The results indicate that the thermal conductivity and thermal diffusivity of cement mortar increase with density. According to these results, the cement mortars with lower densities are better insulation materials in both steady and transient thermal conditions, due to their lower k-value and thermal diffusivity, respectively. The obtained results follow the trend reported in the literature $(10,26,27)$. As expected, the cement mortars with lower densities display lower k-values and thermal diffusivity.

\subsubsection{Compressive strength}

Figure 7 shows the thermal conductivity and diffusivity of cement mortar as a function of 7 -and 28-day compressive strength. These relationships show that, generally, mortars with higher compressive strength have higher thermal conductivity and thermal diffusivity.

\subsubsection{Water absorption}

The water absorption of cement mortar is the flow of fluid inside the porosities of unsaturated cement mortar specimens when there is no external pressure on the samples. Water absorption is used as a quantifying factor when evaluating the durability of cementitious systems (8). Water can penetrate porosities on the surface and those a few millimetres inside the sample. Due to the relationship between water absorption and the porosities inside the material, there should be a relationship between this test and thermal properties. Figure 8 represents the initial and final water absorption of each cement mortar at the age of 28 days. It is apparent that M1:8 has the highest initial and final water absorption. This could be attributed to the higher porosity of mortar with a higher water-to-cement ratio and lower $\mathrm{C} / \mathrm{S}$ ratio.
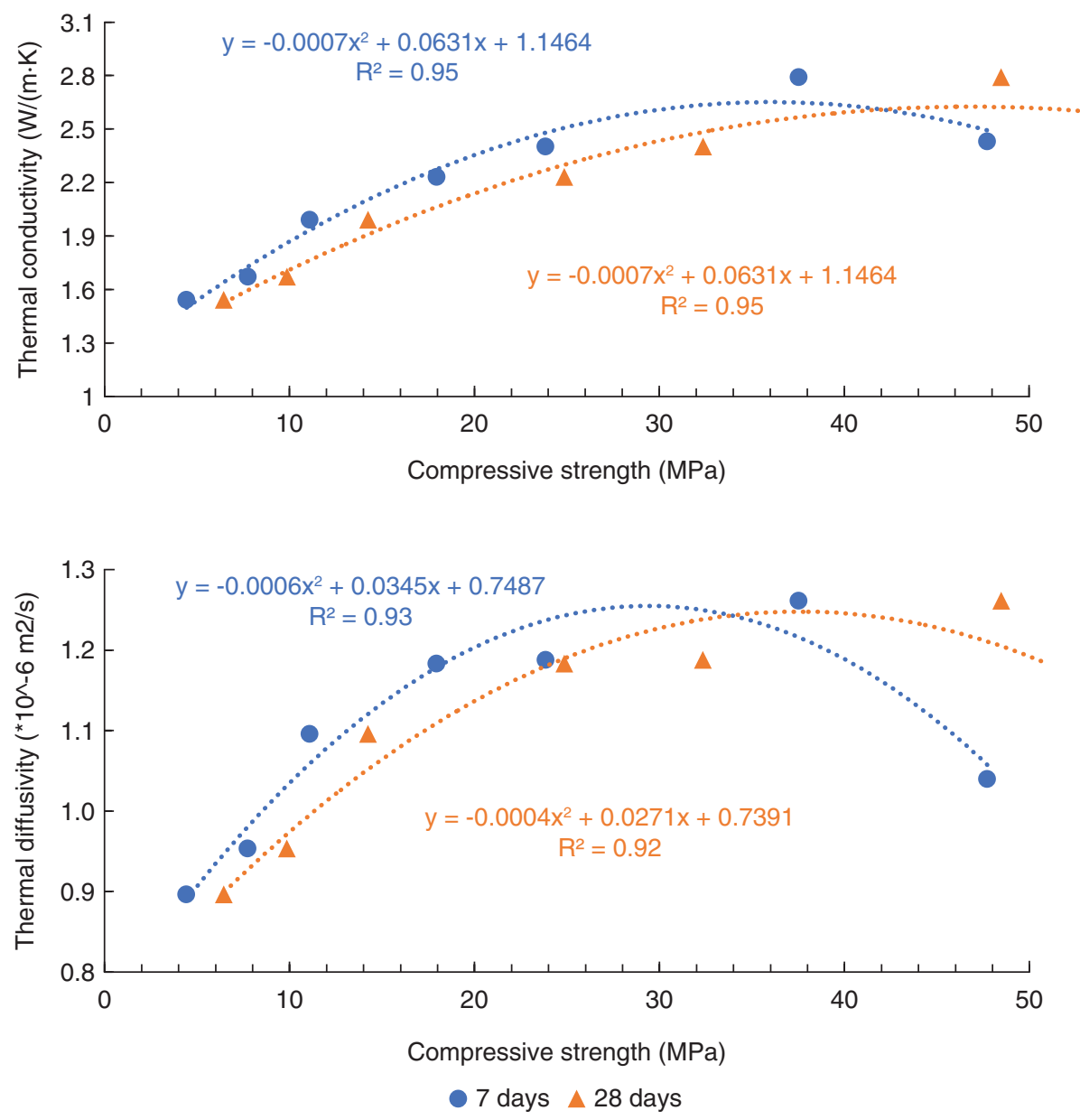

FiguRE 7. The relationship between compressive strength and the thermal properties of cement mortar. 
As represented in Figure 9, there is a strong correlation between initial and final water absorption and the thermal conductivity of cement mortar, with $\mathrm{R}^{2}$ values of 0.93 and 0.95 , respectively. The $\mathrm{k}$-value of cement mortar decreased with each increment in initial and final water absorption.

\subsubsection{Porosity}

The volume of cement mortar that is not composed of solid material is called porosity. Porosity may affect the mechanical and thermal properties of cement-based materials. $(26,28)$ The relationship

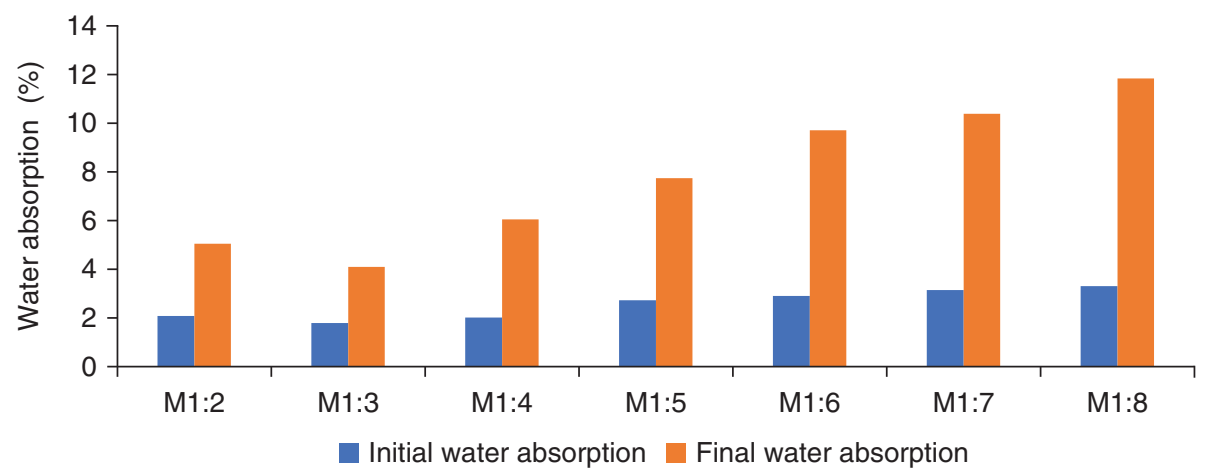

FIGURE 8. Initial and final water absorption.
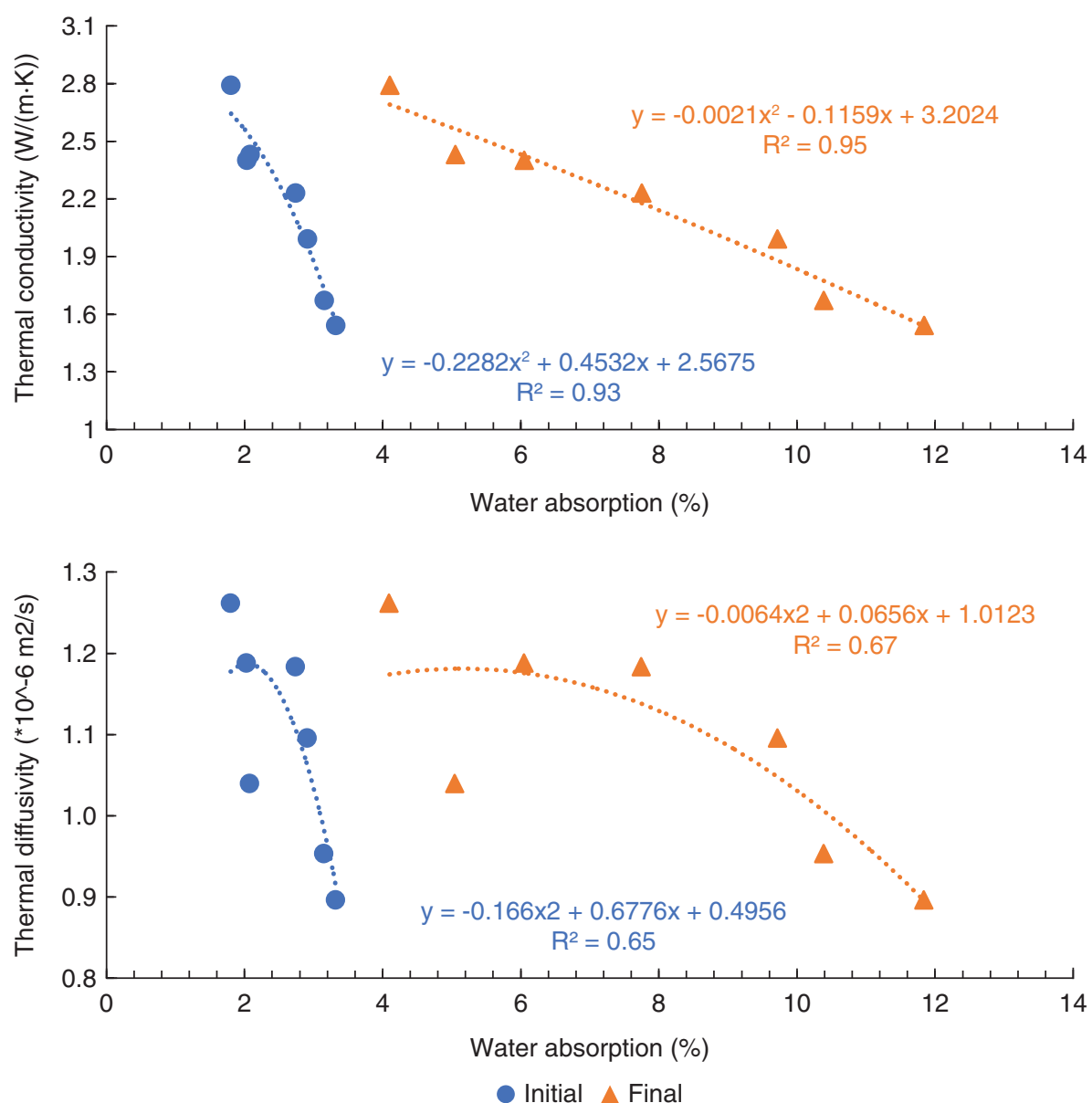

FIGURE 9. The relationship between water absorption and the thermal properties of cement mortar. 

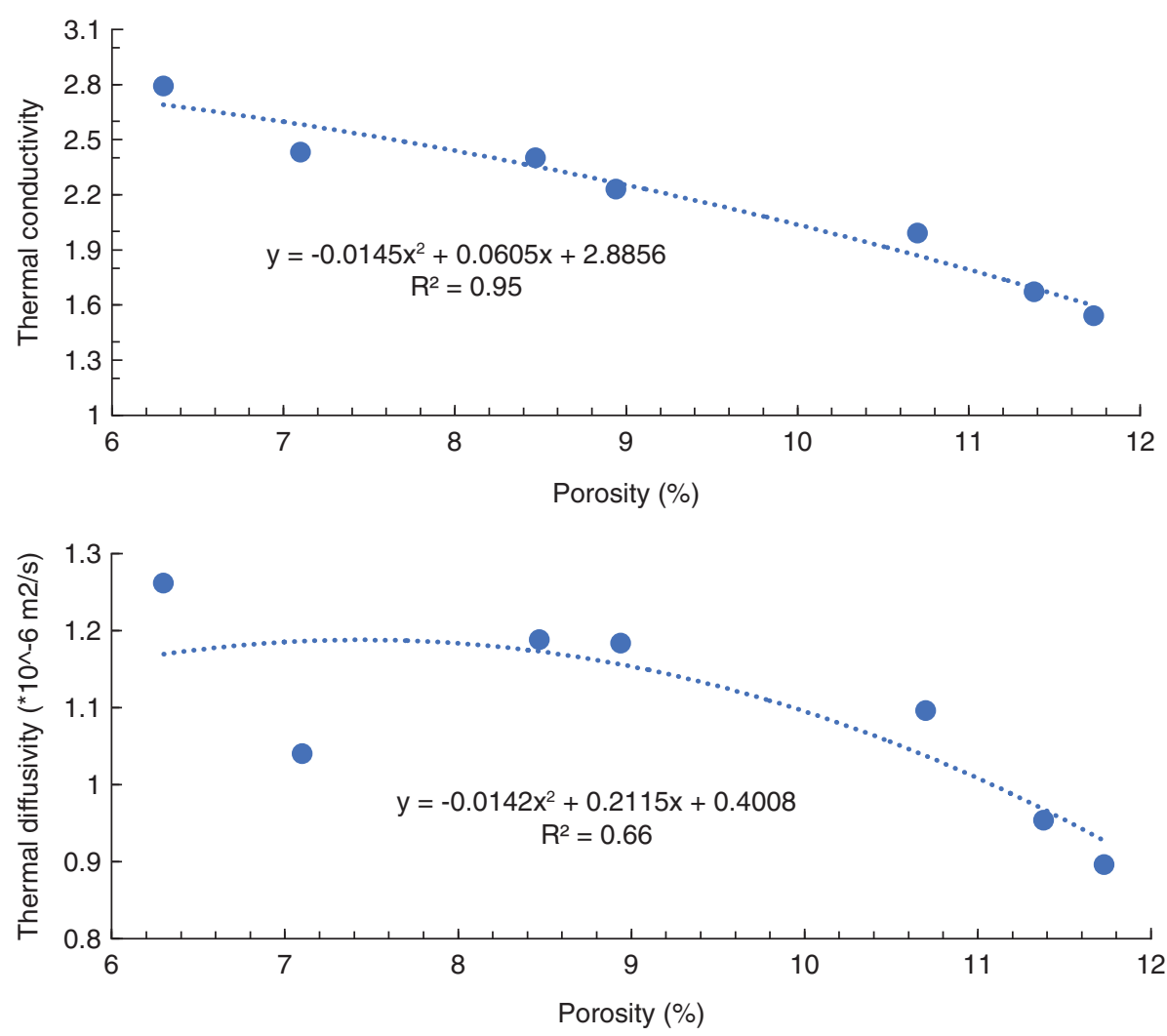

FIGURE 10. The relationship between porosity and thermal properties of cement mortar.

between porosity and the thermal properties of different cement mortars is presented in Figure 10. The $\mathrm{k}$-value and thermal diffusivity decreased by around $45 \%$ and $30 \%$ when porosity increased from $6.3 \%$ to $11.73 \%$.

The available voids inside cement-based materials have a significant effect on their thermal conductivity and diffusivity $(26,28,29)$. The k-value of cement mortar decreases due to the low thermal conductivity of air. The scanning electron microscope (SEM) images of samples M1:2 to M1:8 are shown in Figure 11. As can be seen, the average void size increased in samples where the cement-to-sand ratio rose from 1:2 to 1:8.

\section{CONCLUSIONS}

This study was carried out to assess the thermal properties of cement mortars with different cement-to-sand $(\mathrm{C} / \mathrm{S})$ ratios. Thermal conductivity and thermal diffusivity are important factors when considering the amount of heat transfer in steady-state and transient conditions, respectively. Furthermore, the correlation between thermal conductivity and diffusivity with oven-dry density, compressive strength, water absorption and the porosity of specimens was analysed to derive equations to predict the mortar's thermal properties. From the test results of this experimental work it can be concluded that:

1. Generally, the thermal conductivity (k-value) of a cement mortar declined when the mixture's sand content and water-to-cement ratio increased. The $\mathrm{k}$-value of the lowest-quality cement mortar (mix M1:8) was about 45\% lower than the thermal conductivity of the highestquality cement mortar (mix M1:3).

2. The specific heat capacity (C-value) of the cement mortar with a $\mathrm{C} / \mathrm{S}$ ratio of $1: 8$, with a value of around $0.87 \mathrm{~kJ} / \mathrm{kg} \cdot \mathrm{K}$, was the lowest of all types of cement mortar tested. The $\mathrm{C}$-value of mix M1:2 was about $20 \%$ greater than the $\mathrm{C}$-value of mix M1:8

3. The cement mortar with a $\mathrm{C} / \mathrm{S}$ ratio of $1: 3$ proved to have the highest thermal diffusivity value among all the tested mixes, due to its higher k-value and lower C-value. Mix M1:8 had the lowest thermal diffusivity, about $30 \%$ lower than that of mix M1:3.

4. The average pore size varied between 18.4 $\mu \mathrm{m}$ for mix M1:2 and $946 \mu \mathrm{m}$ for mix M1:8. 

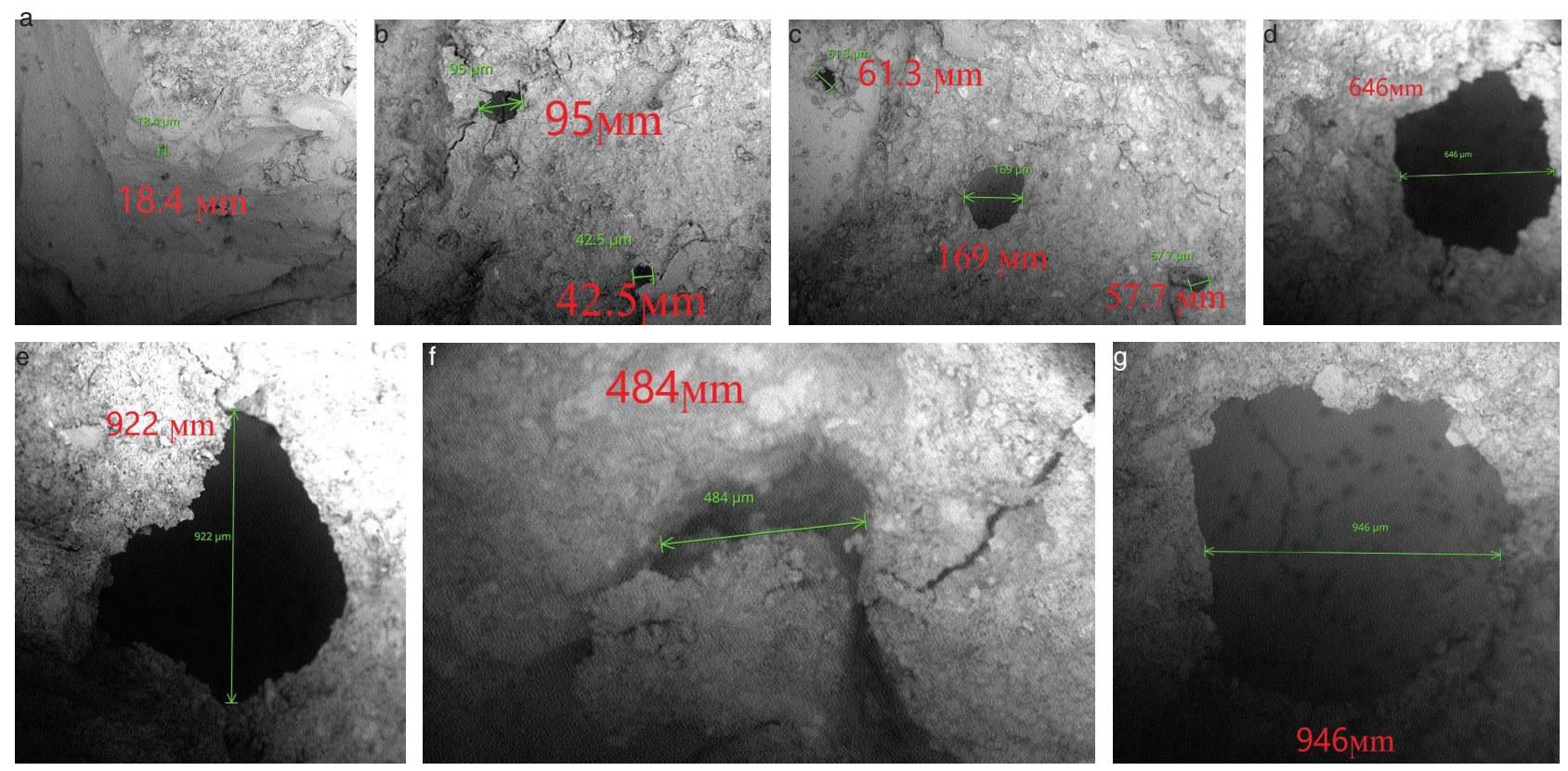

FIgURE 11. Void size in cement mortars with a C/S ratio of a) 1:2, b) 1:3, c) 1:4, d) 1:5, e) 1:6, f) 1:7 and g) 1:8.

The variation in thermal conductivity and diffusivity between different mixes can be attributed to their different pore sizes.

5. Both the k-value and thermal diffusivity of cement mortar increased with dry density, and these properties can be correlated using the following equations:

$$
\begin{gathered}
\mathrm{k}=-2 \mathrm{E}-05 \rho^{2}+0.0672 \rho-72.475\left(\mathrm{R}^{2}=0.92\right), \\
\alpha=-9 \mathrm{E}-06 \rho^{2}+0.0397 \rho-41.529\left(\mathrm{R}^{2}=0.66\right) .
\end{gathered}
$$

6. The k-value and thermal diffusivity of cement mortar increased with compressive strength. These values can be estimated based on compressive strength with a good degree of accuracy as follows:

$$
\begin{aligned}
\mathrm{k}= & -0.0007 \mathrm{fc} 2+0.0631 \mathrm{fc}+1.1464\left(\mathrm{R}^{2}=0.95\right), \alpha \\
& =-0.0004 \mathrm{fc} 2+0.0271 \mathrm{fc}+0.7391\left(\mathrm{R}^{2}=0.92\right)
\end{aligned}
$$

7. There is a correlation between initial and final water absorption and the k-value and thermal diffusivity of cement mortars. The k-value and thermal diffusivity of cement mortar decreased as water absorption increased. The thermal properties of mortar can be estimated based on the final water absorption as follows:

$$
\begin{aligned}
\mathrm{k}= & -0.0021 \mathrm{Wa} 2-0.1159 \mathrm{Wa}+3.2024 \\
& \left(\mathrm{R}^{2}=0.95\right), \alpha=-0.0064 \mathrm{Wa} 2+0.0656 \mathrm{Wa}+ \\
& 1.0123\left(\mathrm{R}^{2}=0.67\right) .
\end{aligned}
$$

8. Both the k-value and thermal diffusivity of a cement mortar decreased with greater porosity. These thermal properties can be estimated using the following equations:

$$
\begin{aligned}
\mathrm{k}= & -0.0145 \varphi 2+0.0605 \varphi+2.8856\left(\mathrm{R}^{2}=0.95\right), \alpha \\
& =-0.0142 \varphi 2+0.2115 \varphi+0.4008\left(\mathrm{R}^{2}=0.66\right) .
\end{aligned}
$$

\section{ACKNOWLEDGMENTS}

The authors gratefully acknowledge financial support from a University of Malaya postgraduate research grant (PPP), with grant no. PG217-2016 A.

\section{REFERENCES}

1. Shafigh, P.; Asadi, I.; Mahyuddin, N.B. (2018) Concrete as a thermal mass material for building applications-A review. J. Build. Eng. 19, 14-25. https://doi.org/10.1016/j. jobe.2018.04.021

2. Bhattacharjee, B.; Krishnamoorthy, S. (2004) Permeable porosity and thermal conductivity of construction materials. J. Mater. Civil Eng. 16 [4], 322-330. https://doi. org/10.1061/(ASCE)0899-1561(2004)16:4(322).

3. Tong, X.C. (2011) Characterization methodologies of thermal management materials. In: Advanced Materials for Thermal Management of Electronic Packaging. 2011, Springer. p. 59-129. https://doi. org/10.1007/978-1-4419-7759-5_2.

4. Zhang, W.; Min, H.; Gu, X.; Xi, Y.; Xing, Y. (2015) Mesoscale model for thermal conductivity of concrete. Constr. Build. Mater. 98, 8-16. https://doi.org/10.1016/j. conbuildmat.2015.08.106. 
5. Kim, K.-H.; Jeon, S.-E.; Kim, J.-K.; Yang, S. (2003) An experimental study on thermal conductivity of concrete. Cem. Concr. Res 33 [3], 363-371. https://doi.org/10.1016/ S0008-8846(02)00965-1.

6. Demirboğa, R. (2003) Influence of mineral admixtures on thermal conductivity and compressive strength of mortar. Energ. Build. 35 [2], 189-192. https://doi.org/10.1016/ S0378-7788(02)00052-X

7. Lertwattanaruk, P.; Makul, N.; Siripattarapravat, C. (2012) Utilization of ground waste seashells in cement mortars for masonry and plastering. J Environ Manage. 111, 133141. https://doi.org/10.1016/j.jenvman.2012.06.032.

8. Mo, K.H.; Bong, C.S.; Alengaram, U.J.; Jumaat, M.Z.; Yap, S.P. (2017) Thermal conductivity, compressive and residual strength evaluation of polymer fibre-reinforced high volume palm oil fuel ash blended mortar. Constr. Build. Mater. 130, 113-121. https://doi.org/10.1016/j. conbuildmat.2016.11.005.

9. Olmeda, J.; De Rojas, M.S.; Frías, M.; Donatello, S.; Cheeseman, C. (2013) Effect of petroleum (pet) coke addition on the density and thermal conductivity of cement pastes and mortars. Fuel. 107, 138-146. https://doi. org/10.1016/j.fuel.2013.01.074.

10. Baite, E.; Messan, A.; Hannawi, K.; Tsobnang, F.; Prince, W. (2016) Physical and transfer properties of mortar containing coal bottom ash aggregates from Tefereyre (Niger). Constr Build Mater. 125, 919-926. https://doi.org/10.1016/j. conbuildmat.2016.08.117.

11. Ruiz-Herrero, J.L.; Nieto, D.V.; López-Gil, A.; Arranz, A.; Fernández, A.; Lorenzana, A.; Merino, S.; De Saja, J.A.; Rodríguez-Pérez, M.Á. (2016) Mechanical and thermal performance of concrete and mortar cellular materials containing plastic waste. Constr Build Mater. 104, 298-310. https://doi.org/10.1016/j.conbuildmat.2015.12.005.

12. Widodo, S.; Ma'arif, F; Gan B.S. (2017) Thermal Conductivity and Compressive Strength of Lightweight Mortar Utilizing Pumice Breccia as Fine Aggregate. Pro. Eng. 171, 768-773. https://doi.org/ 10.1016/j. proeng.2017.01.446.

13. Kockal, N.U. (2016) Investigation about the effect of different fine aggregates on physical, mechanical and thermal properties of mortars. Constr. Build. Mater. 124, 816-825. https://doi.org/10.1016/j.conbuildmat.2016.08.008.

14. Zhang, H. (2011) Building materials in civil engineering. Elsevier.

15. Sandin, K. (1995) Mortars for Masonry and Rendering Choice and Application. In: Building Issues, Vol 7. http:// lup.lub.lu.se/record/526113

16. Malaysian Standard (2003) Portland cement (ordinary and rapid-hardening): Part 1. Specification (Second revision), Malaysia, MS. 522. The Department of Standards Malaysia, (2003)

17. ASTM C1437 (2007) Standard Test Method for Flow of Hydraulic Cement Mortar, ASTM International,
West Conshohocken, PA, 2007. https://doi.org/10.1520/ C1437-07.

18. Blázquez, C.S.; Martín, A.F.; Nieto, I.M.; García, P.C.; Pérez, L.S.S.; González-Aguilera, D. (2017) Analysis and study of different grouting materials in vertical geothermal closed-loop systems. Renew. Energy. 114, 1189-1200. https://doi.org/10.1016/j.renene.2017.08.011.

19. Bentz, D.P.; Peltz, M.A.; Duran-Herrera, A.; Valdez, P.; Juarez, C. (2011) Thermal properties of high-volume fly ash mortars and concretes. J. Build. Phys. 34 [3], 263-275. https://doi.org/10.1177/1744259110376613.

20. Othuman, M.A.; Wang, Y. (2011) Elevated-temperature thermal properties of lightweight foamed concrete. Constr. Build. Mater. 25 [2], 705-716. https://doi.org/10.1016/j. conbuildmat.2010.07.016.

21. Waller, V.; De Larrard, F.; Roussel, P. (1996) Modelling the temperature rise in massive HPC structures. In: 4th International Symposium on Utilization of High-Strength/ High-Performance Concrete. RILEM SARL Paris.

22. Lyons, A. (2014) Materials for architects and builders, Routledge, London.

23. Hashemi, M.; Shafigh, P.; Karim, M.R.B.; Atis, C.D (2018) The effect of coarse to fine aggregate ratio on the fresh and hardened properties of roller-compacted concrete pavement. Constr Build Mater. 169, 553-566. https:// doi.org/10.1016/j.conbuildmat.2018.02.216.

24. ASTM C270-19ae1 (2019) Standard Specification for Mortar for Unit Masonry, ASTM International, West Conshohocken, PA, 2019. https://doi.org/10.1520/ C0270-19AE01.

25. Yüksek, S. (2019) Mechanical properties of some building stones from volcanic deposits of mount Erciyes (Turkey). Mater. Construcc. 69 [334], e187. https://doi.org/10.3989/ mc.2019.04618

26. Asadi, I; Shafigh, P; Hassan, Z.F.B.A; Mahyuddin, N.B. (2018) Thermal conductivity of concrete-A review. J. Build. Eng. 20, 81-93. https://doi.org/10.1016/j.jobe. 2018.07.002

27. Real, S.; Gomes, M.G.; Rodrigues, A.M.; Bogas, J.A. (2016) Contribution of structural lightweight aggregate concrete to the reduction of thermal bridging effect in buildings. Constr Build Mater. 121, 460-470. https://doi. org/10.1016/j.conbuildmat.2016.06.018.

28. Hashemi, M., Shafigh, P., Abbasi, M. and Asadi, I. (2019) The effect of using low fines content sand on the fresh and hardened properties of roller-compacted concrete pavement. Case Studies in Construction Materials, 11, e00230. https://doi.org/10.1016/j.cscm.2019.e00230.

29. Chung, S.-Y.; Han, T.-S.; Kim, S.-Y.; Kim, J.-H.J.; Youm, K.S.; Lim, J.-H. (2016) Evaluation of effect of glass beads on thermal conductivity of insulating concrete using micro CT images and probability functions. Cem. Concr. Compos. 65, 150-162. https://doi.org/10.1016/j. cemconcomp.2015.10.011. 